\title{
Mechanism Analysis of Organic Matter Enrichment of Upper Ordovician-Lower Silurian Shale in the Upper Yangtze Area: Taking Jiaoye-1 Well in the Jiaoshiba Block as an Example
}

\author{
Xiaoxue Liu $\mathbb{D}^{1,2}$ Zhenxue Jiang $\mathbb{D}^{1,2}$ Kun Zhang $\mathbb{D}^{1,2,3,4,5}$ Yan Song $\mathbb{D}^{1,2,4}$ Lin Jiang ${ }^{4}{ }^{4}$ \\ Shu Jiang, ${ }^{6}$ Qixiang Xuan, ${ }^{1,2}$ Ming Wen $\mathbb{D}^{1,2}$ Yizhou Huang $\mathbb{D}^{1,2}$ Xin Wang, ${ }^{1,2}$ Tianlin Liu, ${ }^{1,2}$ \\ and Xuelian Xie ${ }^{7}$ \\ ${ }^{1}$ State Key Laboratory of Petroleum Resources and Prospecting, China University of Petroleum, Beijing 102249, China \\ ${ }^{2}$ Unconventional Natural Gas Institute, China University of Petroleum, Beijing 102249, China \\ ${ }^{3}$ Unconventional Petroleum Collaborative Innovation Center, China University of Petroleum, Beijing 102249, China \\ ${ }^{4}$ Research Institute of Petroleum Exploration and Development, Beijing 100083, China \\ ${ }^{5}$ Energy and Geoscience Institute, University of Utah, Salt Lake City, Utah 84108, USA \\ ${ }^{6}$ Key Laboratory of Tectonics and Petroleum Resources of Ministry of Education, Faculty of Earth Resources, China University \\ of Geosciences, Wuhan 430074, China \\ ${ }^{7}$ Guangzhou Marine Geological Survey, Guangzhou 510760, China
}

Correspondence should be addressed to Zhenxue Jiang; zhenxuejiangedu@126.com, Kun Zhang; shandongzhangkun@126.com, Yan Song; yansongpetrochina@126.com, and Lin Jiang; jianglin01@petrochina.com.cn

Received 26 April 2019; Revised 21 May 2019; Accepted 9 June 2019; Published 4 August 2019

Academic Editor: Andrea Brogi

Copyright (c) 2019 Xiaoxue Liu et al. This is an open access article distributed under the Creative Commons Attribution License, which permits unrestricted use, distribution, and reproduction in any medium, provided the original work is properly cited.

Organic matter is the material basis of shale hydrocarbon generation. The current organic matter content in shale is controlled by the original sedimentary organic matter abundance. Therefore, the study of the enrichment mechanism of sedimentary organic matter in shale has become an important issue to be solved. The Upper Yangtze area is the important exploration and exploitation area of marine shale gas in China. The shale of the Upper Ordovician Wufeng Formation-Lower Silurian Longmaxi Formation in the Yangtze area is the research object. Choosing redox indicator and biological productivity indicator, the study explores the enrichment mechanism of sedimentary organic matter from two aspects, sealing of water and volcanic activity. The results show that excess siliceous mineral in the shale of the Wufeng Formation-Longmaxi Formation in the Upper Yangtze area is bioorigin. Excess siliceous mineral can be used as one of the indicators of biological productivity. On the one hand, layer phenomenon occurred since the strong water sealing during the sedimentary period of Wufeng and the lower section of the Longmaxi Formation, which results in the high content of oxygen in surface water. On the other hand, the active volcanic activity brought volcanic ash which was beneficial to biological reproduction. Both of these factors led to higher biological productivity during this period. At the same time, the strong sealing of water made the lower layer of the water more reductive, and the active volcanic activity caused climate change, enhancing the reduction of the lower layer of the water, which made the rich organic matter deposited from the surface water well preserved. In the sedimentary period of the upper section of the Longmaxi Formation 1st member in the Upper Yangtze area, on the one hand, due to the weakened sealing of water, the oxygen content of the upper water decreased. On the other hand, the volcanic activity weakened until it stopped, and the source of volcanic ash rich in nutrient elements decreased. These two aspects led to lower biological productivity during this period. At the same time, the weaker water sealing could lead to a decrease in the reduction of the lower layer of the water, and the gradual cessation of volcanic activity no longer affected the climate, causing the destruction of sedimentary organic matter by oxidation. 


\section{Introduction}

With the change of exploration thinking and the advancement of hydraulic fracturing technology, shale gas exploration has achieved great success in North America such as Permian Basin, Fort Worth Basin, Appalachian Basin, and Williston Basin [1-6]. China also has huge potential for shale gas, especially the Upper Ordovician Wufeng FormationLower Silurian Longmaxi Formation 1st member in the Sichuan Basin of the Upper Yangtze area. After the oil companies, such as PetroChina and Sinopec, explored the marine shale gas in this stratum, shale gas fields such as Weiyuan, Changning, Zhaotong, Fushun-Yongchuan, Dingshan, and Jiaoshiba have been built since 2010, and good industrial production capacity has been obtained [7-10]. Predecessors did researches on shale reservoir characteristics [11-17], shale gas accumulation mechanism [18-22], and shale gas preservation conditions [23-28] and have yielded a series of scientific research results. Organic matter is the material basis for hydrocarbon generation in shale and is also the main reservoir space and seepage channel for shale gas. The sedimentary environment affects the enrichment of organic matter. So, the analysis of the geological factors affecting the abundance of sedimentary organic matter and the study of the enrichment mechanism of sedimentary organic matter in shale have become the important issues to be solved.

The enrichment mechanism of deposited organic matter in shale has been studied by some researchers. Xia et al. [29] studied the Lower Cambrian Niutitang Formation in the southeastern Chongqing in periphery of Sichuan Basin in the Upper Yangtze area and concluded that the different strata of the Niutitang Formation were affected by the deep hydrothermal fluid brought by the rising ocean current. When the environmental condition reached the reducing condition which was favorable for the preservation of organic matter, the degree of reduction was no longer the main factor determining the degree of organic matter enrichment. Besides, the rising ocean current promoted the enrichment of organic matter and the change of paleoaltitude had little effect on the enrichment of organic matter. Zhang et al. [30] studied the sedimentary environment of the Lower Cambrian shale rich in organic matter in the Upper Yangtze area and concluded that the organic shale in the shelf was mainly controlled by seawater redox conditions, and the organic matter was more easily preserved in the reducing environment. In addition, the organic matter content in the organic-rich shale in the slope-basin area was mainly controlled by the biological primary productivity and sedimentary environment. Under the same sedimentary conditions, the organic matter abundance was higher than in the shelf. Qiu et al. [31], after studying the sedimentary environment of the Wufeng Formation-Longmaxi Formation shale in the Wuxi Block of the Upper Yangtze area, believed that the eustacy controlled the degree of hypoxia in the sedimentary water. The sea level decline made the bottom water rich in oxygen, while the sea level rise made the bottom water lack oxygen, thus controlling the degree of organic matter enrichment in shale.
The large-scale exploration of shale gas in recent years has provided new data for the study of the mechanism of deposited organic matter. Predecessors did researches on the source of siliceous mineral. Holdaway and Clayton [32] defined the concept of excess siliceous mineral, which refers to siliceous minerals beyond the source of normal terrigenous debris, and proposed a quantitative calculation of excess siliceous mineral. Wedepohl [33], Adachi et al. [34], and Yamamoto [35] proposed a method for determining whether siliceous mineral is of hydrothermal origin or bioorigin by using the Al-Fe-Mn ternary diagram. Li et al. [36], Shu et al. [37], and Wu et al. [38], after giving detailed description of the shale core of the Upper Ordovician Wufeng Formation-Lower Silurian Longmaxi Formation, found bentonite in some layers, which was derived from volcanic activity. This paper firstly determines the redox indicator and biological productivity indicator, and then discusses the degree of water sealing and the influence of volcanic activity on sedimentary organic matter enrichment, and establishes the Late Ordovician-Early Silurian sedimentary organic matter enrichment model in the Upper Yangtze area.

\section{Geological Settings}

2.1. Sedimentary and Stratum Characteristics. According to previous studies [39-41], during the period of Cambrian to Silurian, the Yangtze Plate and the Cathaysian Plate gradually collided. As shown in Figure 1, the Upper Yangtze area has a wide area. In the Late Ordovician-Early Silurian, after being squeezed by the Cathaysian Plate, it formed the intracratonic depression basin. This paper takes a set of strata which is widely deposited in the Yangtze Plate during the Late Ordovician-Early Silurian as research layer. Because the Yangtze Plate is large, it has different names in different areas. In the Upper Yangtze area, the Late Ordovician sedimentary strata are called as the Wufeng Formation, and the Early Silurian sedimentary strata are called as the Longmaxi Formation. The target layer of the study is the Wufeng Formation-Longmaxi Formation 1st member, and its lithology is bipartite. The Wufeng Formation-the lower section of the Longmaxi Formation 1st member is mainly black siliceous organic-rich shale and the upper section of the Longmaxi Formation 1st member is a combination of dark grey shale, silty shale, and siltstone.

2.2. Tectonic Characteristics. According to previous studies [46-48], the primitive continental crust of southern China was separated into two ancient plates, Yangtze Plate and Cathaysian Plate, in the Early Mesoproterozoic. In the Early Cambrian, the two plates were in tension and large-scale transgression occurred, depositing a set of organic-rich shale almost throughout the plate. Afterwards, the water gradually became shallower, and the lithology gradually changed from fine shale and silty shale to coarse-grained clastic rock such as siltstone and sandstone. In the Ordovician, being affected by the compression collision of the Cathaysian Plate, the water continued to become shallower and lithology was transformed from a clastic rock sedimentary system to a carbonate rock sedimentary system. A large-scale transgression 


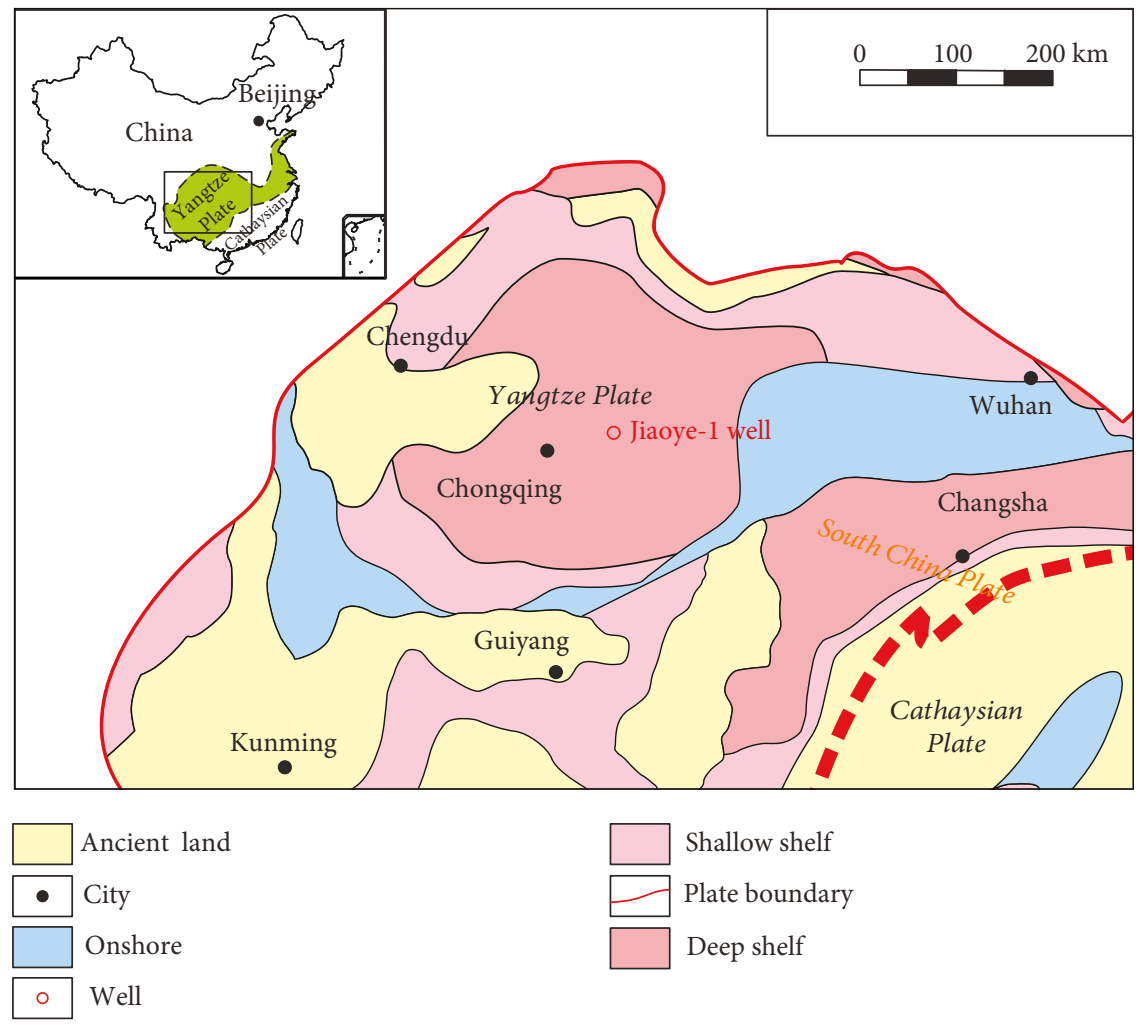

Figure 1: Regional sedimentary characteristics of Late Ordovician-Early Silurian in the Upper Yangtze area, southern China. Modified from Zhu et al. [42], Zhu et al. [43], Liu et al. [44], Zhang et al. [30], and Zhang et al. [45].

occurred in the Late Ordovician-Early Silurian, lithology was changed into a clastic sedimentary system, and a set of organic-rich shale was deposited in a deep shelf surrounded by ancient land. During the period of Cambrian to Silurian, the Cathaysian Plate gradually subducted and collided with the Yangtze plate. At the end of the Silurian, the Yangtze Plate and the Cathaysian Plate were integrated into one and became the unified South China Plate [49].

\section{Samples, Experiments, and Source of Data}

Because of the large sedimentary range of the deep shelf, the small variation of the lithofacies, and the high homogeneity of marine shale, in this study, Jiaoye-1 well, the typical well in the Jiaoshiba Block of the Sichuan Basin, was selected to analyze the enrichment mechanism of the Late OrdovicianEarly Silurian sedimentary organic matter in the Upper Yangtze area. Fifteen debris samples were taken at intervals of $5 \sim 6 \mathrm{~m}$ from the Upper Ordovician Wufeng FormationLower Silurian Longmaxi Formation shale in the Jiaoye-1 well and $\mathrm{Al}, \mathrm{Fe}$, and $\mathrm{Mn}$ were analyzed by Axios-MAX $\mathrm{X}$-ray Fluorescence. Forty-five core samples were taken from the Wufeng Formation-Longmaxi Formation in the Jiaoye-1 well, and TOC content and whole rock mineral composition were experimented by OG-2000V total organic carbon analyzer and Ultima IV X-ray diffraction full rock analyzer.

In this paper, 20 samples were taken from the bentonite in the shale of the Jiaoye-1 well. The main element and trace element were analyzed by PE Elan 6000 inductively coupled plasma mass spectrometer (ICP-MS). Some of the data were referenced in the data of Wang et al. [50], Luo et al. [51], Hu et al. [52], and Tang et al. [53]. Besides, 2 samples from the Wufeng Formation and 10 samples from the Longmaxi Formation 1st member were selected to measure content of molybdenum by PE Elan 6000 inductively coupled plasma mass spectrometer (ICP-MS) and excess molybdenum $\left(\mathrm{Mo}_{\mathrm{XS}}\right)$ was calculated. This paper collected the calculation data of excess molybdenum $\left(\mathrm{Mo}_{\mathrm{XS}}\right)$ of the biological productivity of the Wufeng Formation-Longmaxi Formation in the Jiaoye-1 well in Guo et al. [54] and collected the logging data of $\mathrm{Si}, \mathrm{Al}, \mathrm{U}$, and $\mathrm{Th}$ of the Jiaoye- 1 well provided by Schlumberger.

\section{Results and Discussion}

\subsection{Indicator of Redox Environment and Biological Productivity}

4.1.1. Indicator of Redox Environment. Determining sedimentary environments by using elemental geochemical indicators is a common method. By analysis of the whole rock, Jones and Manning [55] had a proposal that U/Th ratio can reflect the sedimentary redox conditions. Generally speaking, U/Th $>1.25$ reflects an anoxic environment, $\mathrm{U} / \mathrm{Th}$ ratio between 0.75 and 1.25 reflects a dysoxic environment, and $\mathrm{U} / \mathrm{Th}<0.75$ reflects an oxidizing environment. Chen et al. [56], Zhao et al. [57], and Wang et al. [58] also used this ratio to determine the redox environment of south 
TABLE 1: U/Th ratios of the Upper Ordovician Wufeng Formation-Lower Silurian Longmaxi Formation 1st member in the Jiaoye-1 well in the Upper Yangtze area. See Figure 1 for the well location.

\begin{tabular}{|c|c|c|c|c|}
\hline \multirow{2}{*}{ Formation } & \multirow{2}{*}{ Depth (m) } & \multicolumn{3}{|c|}{ Proportion (\%) } \\
\hline & & $\mathrm{U} / \mathrm{Th}<0.75$ & $0.75<\mathrm{U} / \mathrm{Th}<1.25$ & $\mathrm{U} / \mathrm{Th}>1.25$ \\
\hline Wufeng & $2411 \sim 2415$ & 15.15 & 66.67 & 18.18 \\
\hline Longmaxi & $2406 \sim 2411$ & 0.00 & 17.50 & 82.50 \\
\hline Longmaxi & $2386 \sim 2406$ & 28.75 & 60.00 & 11.25 \\
\hline Longmaxi & $2326 \sim 2386$ & 95.42 & 4.58 & 0.00 \\
\hline
\end{tabular}

TABle 2: Values of excess molybdenum $\left(\mathrm{Mo}_{\mathrm{XS}}\right)$ of the Upper Ordovician Wufeng Formation-Lower Silurian Longmaxi Formation 1st member in the Jiaoye-1 well in the Upper Yangtze area. See Figure 1 for the well location.

\begin{tabular}{|c|c|c|c|c|c|c|c|}
\hline Sample & Formation & Depth (m) & $\mathrm{Mo}_{\mathrm{XS}}(\mathrm{ppm})$ & Sample & Formation & Depth $(\mathrm{m})$ & $\mathrm{Mo}_{\mathrm{XS}}(\mathrm{ppm})$ \\
\hline 1 & Wufeng & 2415.00 & 2.78 & 11 & Longmaxi & 2375.89 & 14.44 \\
\hline 2 & Wufeng & 2412.55 & 90.28 & 12 & Longmaxi & 2373.83 & 11.11 \\
\hline 3 & Longmaxi & 2402.39 & 42.43 & 13 & Longmaxi & 2370.78 & 10.26 \\
\hline 4 & Longmaxi & 2398.51 & 40.28 & 14 & Longmaxi & 2367.02 & 13.89 \\
\hline 5 & Longmaxi & 2394.36 & 29.17 & 15 & Longmaxi & 2358.53 & 9.92 \\
\hline 6 & Longmaxi & 2391.49 & 27.78 & 16 & Longmaxi & 2337.55 & 2.78 \\
\hline 7 & Longmaxi & 2388.1 & 26.89 & 17 & Longmaxi & 2341.81 & 18.06 \\
\hline 8 & Longmaxi & 2385.00 & 37.50 & 18 & Longmaxi & 2349.26 & 19.44 \\
\hline 9 & Longmaxi & 2381.82 & 17.43 & 19 & Longmaxi & 2332.44 & 5.92 \\
\hline 10 & Longmaxi & 2379.36 & 19.44 & & & & \\
\hline
\end{tabular}

of the Sichuan Basin. This paper used the same method. Using this ratio and classification, results are as follows. As is shown in Table 1, U/Th ratios of the Wufeng Formation $(2411 \mathrm{~m} \sim 2415 \mathrm{~m})$ are mostly $0.75 \sim 1.25$, meaning an oxygen deficiency oxidation environment. The U/Th ratios of the bottom of the lower section of the Longmaxi Formation 1st member $(2406 \mathrm{~m} \sim 2411 \mathrm{~m})$ are principally more than 1.25, with a maximum of 3.73 , showing an anaerobic environment. Most of the U/Th ratios of the lower section of the Longmaxi Formation 1st member $(2386 \mathrm{~m} \sim 2406 \mathrm{~m})$ are $0.75 \sim 1.25$, suggesting an oxygen deficiency oxidation environment. Most of the U/Th ratios of the upper section of the Longmaxi Formation 1st member (2326 m 2386 m) are less than 0.75 , with a minimum of 0.17 , reflecting an oxidation environment.

\subsubsection{Indicator of Biological Productivity}

(1) Excess Molybdenum. The content of molybdenum is a widely used indicator reflecting the productivity of paleoocean organism. Molybdenum has two origins, terrestrial detrital and biological origin. Mo, which is only derived from biological action, is called excess molybdenum $\left(\mathrm{Mo}_{\mathrm{Xs}}\right)$ and content can be calculated by the following formula.

$$
\mathrm{Mo}_{\mathrm{xs}}=\mathrm{Mo}_{\mathrm{s}}-\mathrm{Al}_{\mathrm{s}}\left(\frac{\mathrm{Mo}}{\mathrm{Al}}\right)_{\mathrm{PAAS}} .
$$

$\mathrm{Mo}_{\mathrm{s}}$ is the content of molybdenum in the sample, and $\mathrm{Al}_{\mathrm{s}}$ is the content of aluminum in the sample. The $(\mathrm{Mo} / \mathrm{Al})_{\text {PAAS }}$ value is 0.00001368 , which is the average content in PostArchaean Australian shale.

Besides, 7 data points are from Guo et al. [54]. And all $\mathrm{Mo}_{\mathrm{Xs}}$ values are as follows (Table 2).

(2) Siliceous Mineral from Bioorigin. The sources of siliceous mineral can be divided into 3 types, terrestrial detrital origin formed in normal condition, hydrothermal origin, and bioorigin formed in special condition [59-63]. Excess siliceous mineral (abbreviation: $\mathrm{Si}_{\mathrm{ex}}$ ) refers to siliceous mineral excepting terrestrial detrital origin, and content can be calculated by the following formula.

$$
\mathrm{Si}_{\mathrm{ex}}=\mathrm{Si}_{\mathrm{s}}-\left[\left(\frac{\mathrm{Si}}{\mathrm{Al}}\right)_{\mathrm{bg}} \times \mathrm{Al}_{\mathrm{s}}\right]
$$

$\mathrm{Si}_{\mathrm{s}}$ is the content of silicon in the sample, and $\mathrm{Al}_{\mathrm{s}}$ is the content of aluminum in the sample. The $(\mathrm{Si} / \mathrm{Al})_{\mathrm{bg}}$ value is 3.11 , which is the average content in shale [32].

The excess siliceous mineral content of the Upper Ordovician Wufeng Formation-Lower Silurian Longmaxi Formation 1st member in the Jiaoye-1 well was calculated, and the result is shown in Figure 2. The siliceous mineral from the upper section of the Longmaxi Formation 1st member is basically of terrigenous detrital origin, while the siliceous mineral from the Wufeng Formation-the lower section of the Longmaxi Formation 1st member contains 


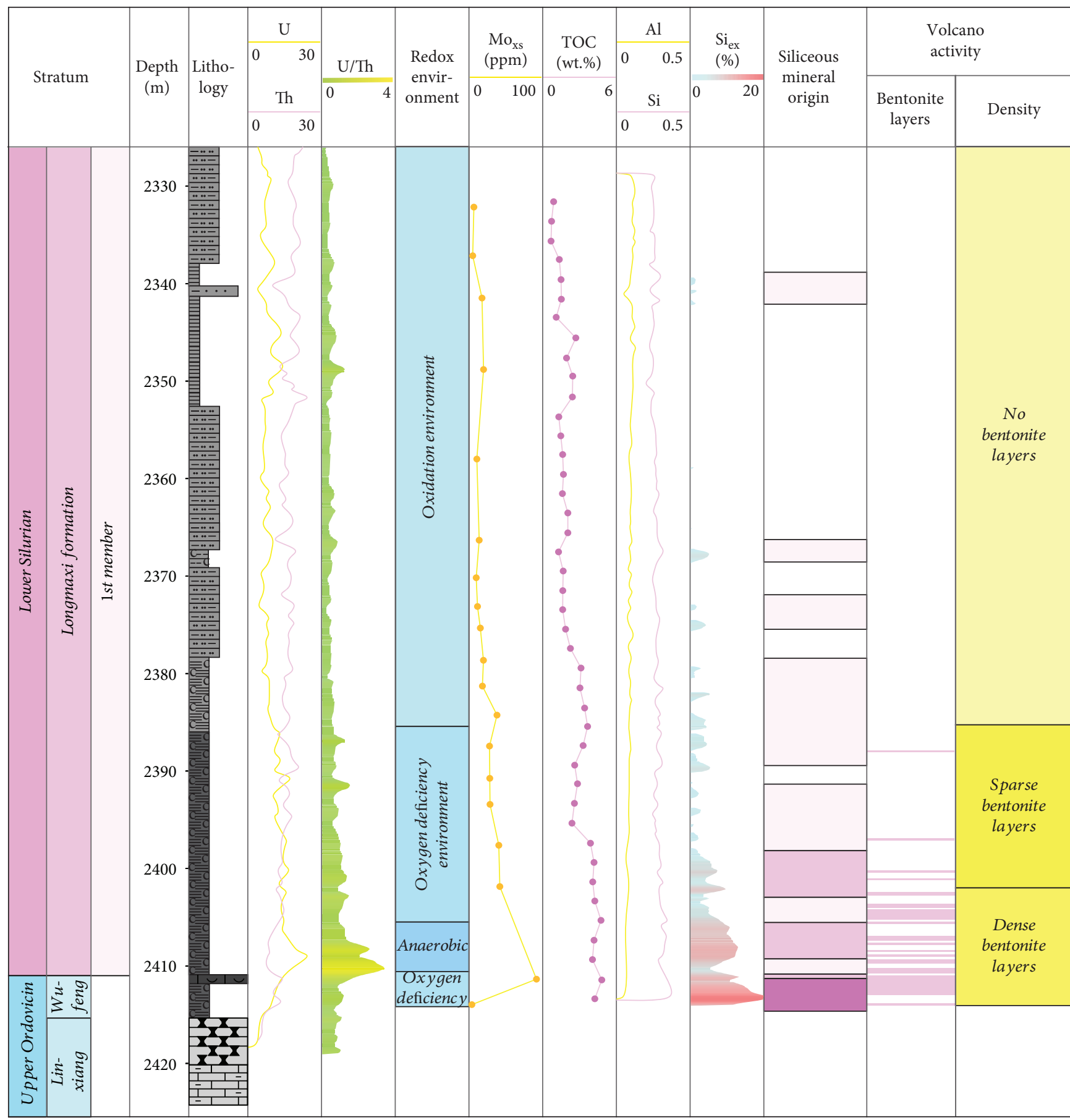

$\square$ Terrestrial detrital origin

Terrestrial detrital origin $+10 \% \sim 15 \%$ bio-origin

Terrestrial detrital origin $+0 \% \sim 5 \%$ bio-origin
Terrestrial detrital origin $+15 \% \sim 20 \%$ bio-origin

Terrestrial detrital origin $+5 \% \sim 10 \%$ bio-origin

FIGURE 2: Synthesis column map of redox environment, excess molybdenum $\left(\mathrm{Mo}_{\mathrm{XS}}\right)$, TOC content, excess siliceous mineral, and bentonite layers of the Upper Ordovician Wufeng Formation-Lower Silurian Longmaxi Formation 1st member in the Jiaoye-1 well in the Upper Yangtze area. See Figure 1 for the well location.

excess siliceous mineral. By analysis of the mineral composition of shale, the siliceous mineral content from the Wufeng Formation-the lower section of the Longmaxi Formation 1st member is higher, 40\% 70\%. And the siliceous mineral content from the upper section of the Longmaxi Formation 1st member gradually decreases to $20 \% \sim 35 \%$. In the intervals with excess siliceous mineral of the Wufeng Formation-the lower section of the Longmaxi Formation, the excess siliceous mineral content in more than half of the intervals is $0 \% \sim 5 \%$, and the excess siliceous mineral content in a part 


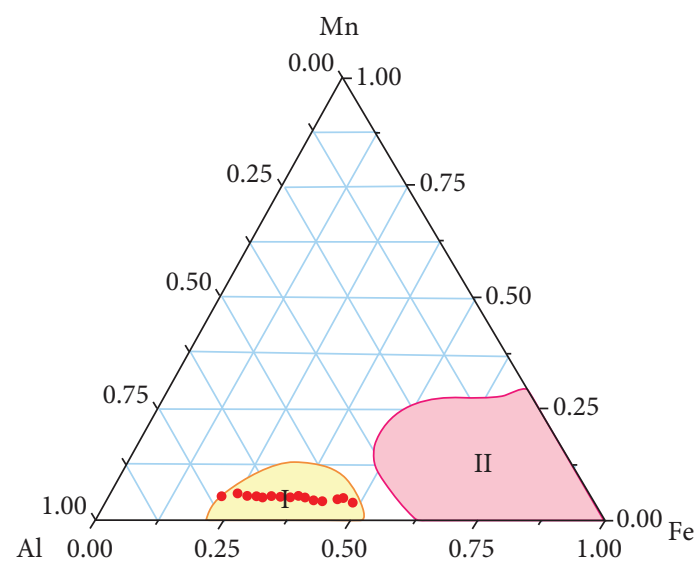

Figure 3: Al-Fe-Mn ternary diagram to analyze the source of siliceous mineral from the Wufeng Formation-Longmaxi Formation 1st member with excess siliceous mineral of the Jiaoye-1 well. Excess siliceous mineral is derived from bioorigin. The base map is from Wedepohl [33], Adachi et al. [34], and Yamamoto [35]. See Figure 1 for the well location. I: bioorigin; II: hydrothermal origin.

of the intervals is $5 \% \sim 15 \%$, and the maximal content is $15 \% \sim 20 \%$.

Wedepohl [33], Adachi et al. [34], and Yamamoto [35] put forward a method for determining whether siliceous minerals are of hydrothermal origin or bioorigin by using the Al-Fe-Mn ternary diagram. In this paper, the measured values of $\mathrm{Al}, \mathrm{Fe}$, and $\mathrm{Mn}$ element of the Wufeng Formation-Longmaxi Formation 1st member with excess siliceous mineral of the Jiaoye- 1 well were placed on the ternary diagram. As shown in Figure 3, it can be found that the values basically fell in the bioorigin area, indicating that the excess siliceous mineral is of bioorigin. According to this, the sources of excess siliceous mineral in the vertical dimension are accurately described in Figure 2. The siliceous mineral derived from bioorigin is from plankton, such as diatoms [63-67]. As a result, similar as excess molybdenum $\left(\mathrm{Mo}_{\mathrm{XS}}\right)$, the siliceous mineral derived from bioorigin can also reflect biological productivity.

4.2. Analysis of Water Sealing and Its Effect on Sedimentary Organic Matter Enrichment. The degree of sealing of water can be reflected by the relationship between Mo and TOC content $[30,40,68,69]$. Based on the base map from Algeo and Lyons [68] and Zhang et al. [30], 11 data points of the upper section of the Longmaxi Formation 1st member and 9 data points of the Wufeng Formation-the lower section of the Longmaxi Formation 1st member of the Jiaoye-1 well are placed on the diagram, respectively. Figure 4 illustrates that Mo and TOC content are mainly in strong restriction. The distribution range of the 11 data points from the upper section of the Longmaxi Formation 1st member indicates that its sealing degree is similar to today's Framvaren (Figure 4(a)). The distribution range of 9 data points from the Wufeng Formation-the lower section of the Longmaxi Formation 1st member indicates that the sealing degree is similar to that of the Black Sea whose sealing is stronger nowadays (Figure 4(b)). This shows that the sealing of water during the Late Ordovician-Early Silurian is stronger, and the sealing during the deposition of the Wufeng Formation-the lower section of the Longmaxi Formation 1st member is stronger than that during the deposition of the upper section of the Longmaxi Formation 1st member.

The analysis results of sealing are consistent with the tectonic background of the Late Ordovician-Early Silurian. Figure 1 demonstrates that during the deposition of the Wufeng Formation-the lower section of the Longmaxi Formation 1st member, there was a strong collision between the Yangtze Plate and the Cathaysian Plate, and shale rich in organic matter was deposited in the deep shelf limited by ancient land, poor connection with the open sea, leading to strong sealing; while during the deposition of the upper Longmaxi Formation 1st member, the collision and compression between the Yangtze Plate and the Cathaysian Plate weakened, and the water became shallower and sealing became weaker.

The sealing of water is one of the major reasons for the difference in redox environment and biological productivity between the Wufeng Formation-the lower section of the Longmaxi Formation and the upper section of the Longmaxi Formation. Due to the strong sealing of water during the deposition of the Wufeng Formation-the lower section of the Longmaxi Formation, layer phenomenon occurred, making the upper water rich in oxygen and the lower water lack in oxygen. The abundant oxygen in the upper water supplied the growth, living, and reproduction of plankton, producing rich source of organic matter, while the anoxic lower water kept sedimentary organic matter from decomposition, which was beneficial for the preservation of organic matter [70-72]. During the deposition of the Longmaxi Formation 1st member, the sealing of water weakened, the anoxic lower water gradually mixed with warm upper water rich in oxygen, bringing that the lower water became warmer, and reducing environment was damaged and sedimentary organic matter was diluted and oxidative decomposed, while the oxygen content of the upper water decreased, the upper water became colder, and biological productivity declined. These two aspects made organic matter abundance descend.

4.3. Volcanic Activity Analysis and Its Effect on the Enrichment of Sedimentary Organic Matter. Bentonite occurs at the Wufeng Formation-Longmaxi Formation 1st member. As the product of sedimentation and alteration of tuffaceous materials, bentonite reveals information of volcanic activity. The thickness of bentonite can be used as direct evidence of volcanic eruption interval and reflect the activity frequency of volcanic eruption [37, 38, 73, 74]. As shown in Figure 2, according to the density of bentonite development, the Wufeng Formation-Longmaxi Formation is divided to $3 \mathrm{sec}$ tions. The Wufeng Formation-the lower section of the Longmaxi Formation is the dense bentonite layer, representing frequent volcanic activity. The middle section of the Longmaxi Formation is the rare bentonite layer, reflecting weakened volcanic activity. The upper section of the Longmaxi Formation is no bentonite layer, showing the stop of volcanic activity. The major elements and trace elements 


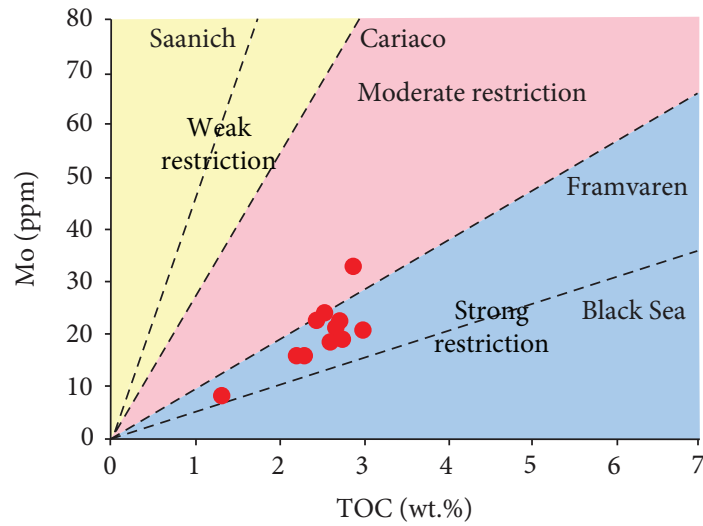

(a)

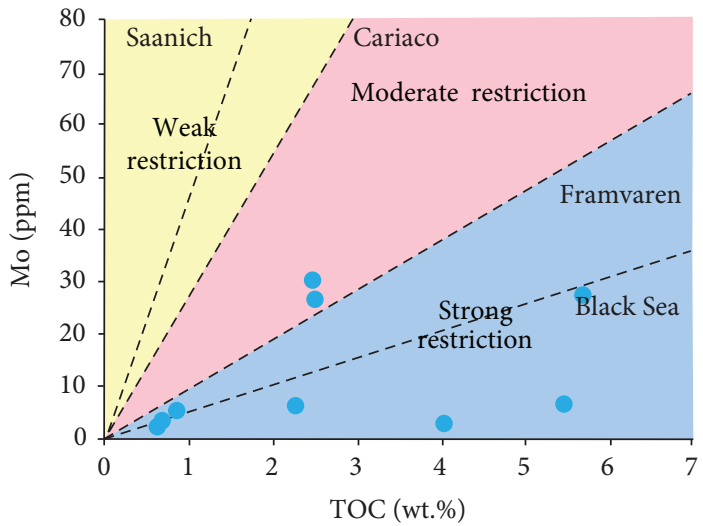

(b)

Figure 4: Mo content-TOC content of the Upper Ordovician Wufeng Formation-Lower Silurian Longmaxi Formation 1st member of the Jiaoye-1 well. (a) The upper section of the Longmaxi 1st member; (b) the Wufeng Formation-the lower section of the Longmaxi Formation. The base map is from Algeo and Lyons [68] and Zhang et al. [30]. See Figure 1 for the well location.

TABLE 3: The major elements and trace elements of 20 bentonite samples. Some of the data were referenced in the data of Wang et al. [50], Luo et al. [51], Hu et al. [52], and Tang et al. [53].

\begin{tabular}{|c|c|c|c|c|c|c|c|c|}
\hline \multirow{2}{*}{ Sample } & \multicolumn{3}{|c|}{ Major elements (\%) } & \multicolumn{3}{|c|}{ Trace elements (ppm) } & \multicolumn{2}{|c|}{ Ratios } \\
\hline & $\mathrm{SiO}_{2}$ & $\mathrm{Al}_{2} \mathrm{O}_{3}$ & $\mathrm{TiO}_{2}$ & $\mathrm{Nb}$ & $\mathrm{Y}$ & $\mathrm{Zr}$ & $\mathrm{Nb} / \mathrm{Y}$ & $\mathrm{Zr} / \mathrm{TiO}_{2}$ \\
\hline 1 & 54.31 & 23.74 & 0.79 & 20.74 & 48.83 & 418.90 & 0.42 & 0.05 \\
\hline 2 & 70.63 & 11.79 & 0.50 & 26.00 & 19.30 & 158.00 & 1.35 & 0.03 \\
\hline 3 & 48.91 & 27.39 & 0.51 & 12.47 & 29.91 & 260.00 & 0.42 & 0.05 \\
\hline 4 & 71.35 & 13.55 & 0.46 & 11.10 & 34.10 & 152.00 & 0.33 & 0.03 \\
\hline 5 & 70.05 & 13.88 & 0.47 & 10.70 & 37.50 & 170.00 & 0.29 & 0.04 \\
\hline 6 & 68.34 & 14.25 & 0.55 & 10.80 & 35.70 & 160.00 & 0.30 & 0.03 \\
\hline 7 & 69.53 & 14.10 & 0.38 & 10.70 & 41.70 & 204.00 & 0.26 & 0.05 \\
\hline 8 & 57.19 & 21.39 & 0.58 & 18.80 & 20.50 & 206.00 & 0.92 & 0.04 \\
\hline 9 & 65.49 & 13.54 & 0.67 & 17.90 & 22.50 & 285.00 & 0.80 & 0.04 \\
\hline 10 & 58.59 & 20.51 & 0.60 & 19.70 & 21.50 & 207.00 & 0.92 & 0.03 \\
\hline 11 & 63.23 & 15.69 & 0.65 & 23.30 & 196.00 & 220.00 & 0.12 & 0.03 \\
\hline 12 & 67.92 & 14.94 & 0.64 & 13.50 & 125.00 & 162.00 & 0.11 & 0.03 \\
\hline 13 & 64.84 & 15.59 & 0.60 & 13.50 & 130.00 & 164.00 & 0.10 & 0.03 \\
\hline 14 & 49.46 & 24.54 & 1.57 & 214.00 & 115.00 & 1363.00 & 1.86 & 0.09 \\
\hline 15 & 47.23 & 25.16 & 0.38 & 21.20 & 40.60 & 359.00 & 0.52 & 0.09 \\
\hline 16 & 36.32 & 9.81 & 0.56 & 12.70 & 13.90 & 155.00 & 0.91 & 0.03 \\
\hline 17 & 56.83 & 23.67 & 0.50 & 7.59 & 51.30 & 144.00 & 0.15 & 0.03 \\
\hline 18 & 60.82 & 21.61 & 0.46 & 8.22 & 55.30 & 148.00 & 0.15 & 0.03 \\
\hline 19 & 51.69 & 25.57 & 0.46 & 15.10 & 51.80 & 265.00 & 0.29 & 0.06 \\
\hline 20 & 51.48 & 25.68 & 0.45 & 14.90 & 50.60 & 264.00 & 0.29 & 0.06 \\
\hline
\end{tabular}

of 20 bentonite samples (Table 3 ) are put on the discrimination diagram, and the base map is from Winchester and Floyd [75]. As can be seen from Figure 5, the volcanic materials forming bentonite are mainly trachyandesite, rhyodacite dacite, and andesite, all of which are intermediate-acidic magmatic rocks originating from deep in the crust.

Volcanic activity is another reason for the difference in redox environment and biological productivity between the Wufeng Formation-the lower section of the Longmaxi
Formation 1st member and the upper section of the Longmaxi Formation 1st member. Influenced by the collision between the Yangtze Plate and the Cathaysian Plate, during the deposition of the Wufeng Formation-the lower section of the Longmaxi Formation 1st member, volcanic activity was frequent and intense, leading to dramatic climate changes, improving the reducibility of the lower water [37, 38, 76-80]. After the ash materials formed by volcanic eruption subsiding into surface water, minerals 


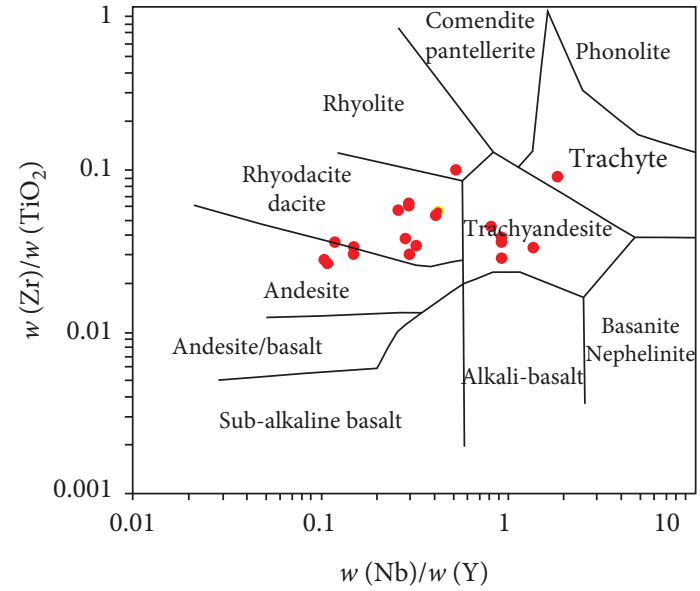

FIGURE 5: Primary magmatic composition discrimination diagram of bentonite samples of the Upper Ordovician Wufeng FormationLower Silurian Longmaxi Formation 1st member in the Jiaoye-1 well. The base map is from Winchester and Floyd [75]. See Figure 1 for the well location.

rich in $\mathrm{Fe}, \mathrm{P}$, and other nutrient elements for the propagation of plankton could be provided by hydrolysis, which was conducive to the improvement of biological productivity [37, 38, 81-84].

Data from the Jiaoye- 1 well proves the above text. As described in Figure 2, data from the Jiaoye-1 well shows that due to the strong collision between the Yangtze Plate and the Cathaysian Plate, the sealing of water is strong and the volcanic activity is active during the deposition of the Wufeng Formation-the lower section of the Longmaxi Formation 1st member, causing the U/Th ratio, the indicator of redox environment, to be the highest around 3 at the bottom of Longmaxi Formation. With the collision between two plates weakening, the sealing of water reduces and volcanic activity weakens and even stops during the deposition of the upper section of the Longmaxi Formation 1st member, causing the $\mathrm{U} / \mathrm{Th}$ ratio to reduce to 0.5 from the bottom upward. The environment is gradually changed from anoxic environment to dysoxic environment, and then to oxidizing environment. Two indicators of biological productivity, excess molybdenum $\left(\mathrm{Mo}_{\mathrm{XS}}\right)$ and silicon derived from bioorigin, show the same trend. During the sedimentation period of the Wufeng Formation-the lower section of the Longmaxi Formation 1st member, due to the strong water sealing and active volcanic activity, the two biological productivity indicators are both high; while during the sedimentation period of the upper section of the Longmaxi Formation 1st member, due to the weak water sealing and weakened and even stopped volcanic activity, these two biological productivity indicators are significantly reduced.

The strong sealing of water and active volcanic activity result in high biological productivity and reducing environment during the deposition of the Wufeng Formation-the lower section of the Longmaxi Formation 1st member, making the TOC content range in $2 \% \sim 5 \%$ in this interval. With the water sealing weakening and volcanic activity gradually stopping, the TOC content of the upper section of the Longmaxi Formation 1st member descends to 0\% 2\% (Figure 2).

4.4. Models of Organic Matter Enrichment during the Deposition of the Upper Ordovician-Lower Silurian in the Upper Yangtze Area. As reflected in Figure 6(a), during the deposition of the Upper Ordovician Wufeng Formation-the lower section of the Lower Silurian Longmaxi Formation 1st member, due to the strong collision between the Yangtze Plate and the Cathaysian Plate, the deep shelf surrounded by ancient land is formed in the Upper Yangtze area, leading to poor connection with the sea and the strong sealing of water, which cause the stratification phenomenon of water. Meanwhile, due to the collision, the volcanic activity occurs in the ancient land surrounding the deep shelf, producing much ash. Volcanic materials are neutral-acidic magmatic rocks derived from deep in the crust. On the one hand, strong sealing led to high content of oxygen in upper water. On the other hand, lots of ash bring nutrient elements that are beneficial for plankton to grow and breed. Both factors cause the high biological productivity. Strong sealing and active volcanic activity can also make the lower water more reducible, which is conducive to the preservation of rich organic matter deposited from the upper layer, leading to the enrichment of sedimentary organic matter.

As depicted in Figure 6(b), during the deposition of the upper section of the Lower Silurian Longmaxi Formation 1 st member, on the one hand, because of the weak collision between the Yangtze Plate and the Cathaysian Plate, the water becomes shallower, weakening the sealing, causing the hypoxic water in the lower layer to be mixed with the warm oxygen-rich water in the upper layer, and then, the reduction environment in the lower layer is damaged, and the oxygen content in the upper layer decreases and the water temperature becomes colder. On the other hand, with the collision weakening, volcanic activity becomes weak and even stops. So the source of ash declines; in other words, the nutrient elements beneficial for plankton to breed decrease. These two factors make the biological productivity of surface water decrease. Weakened sealing and gradually stopped volcanic activity reduce the reducing property of the lower water, causing the sedimentary organic matter from the upper layer to be damaged, which is not conducive to the accumulation of sedimentary organic matter.

\section{Conclusions}

The paper takes the marine shale of the Upper Ordovician Wufeng Formation-Lower Silurian Longmaxi Formation 1st member in the Upper Yangtze area, southern China, as the research objective interval. As the typical well, Jiaoye-1 well located in Sichuan Basin, Upper Yangtze area is the source of samples in the following experiments. The TOC content and mineral composition, major elements, and trace elements are analyzed by experiments on shale cores, shale debris, and bentonite cores, collecting the logging data to study the mechanism of sedimentary organic matter enrichment, and conclusions are as follows. 


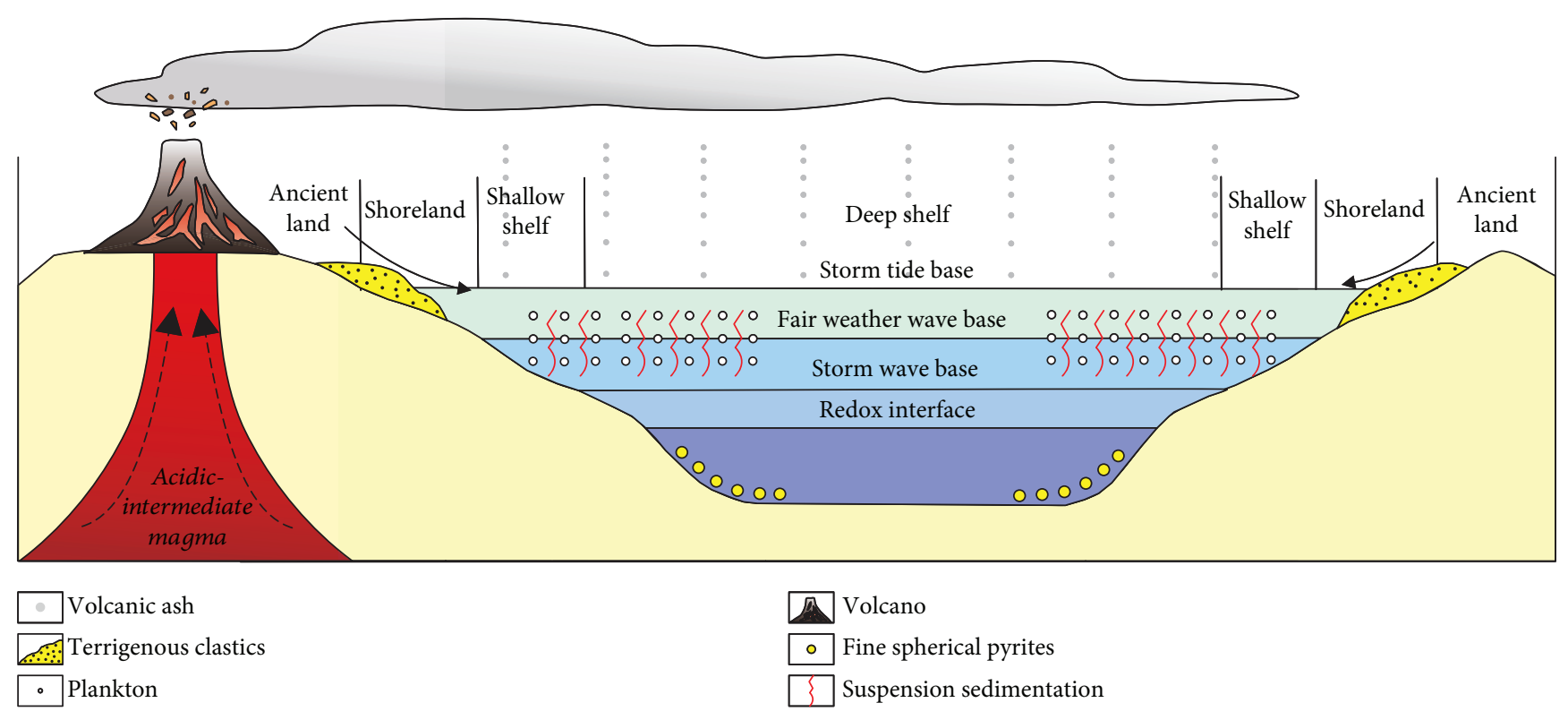

(a)

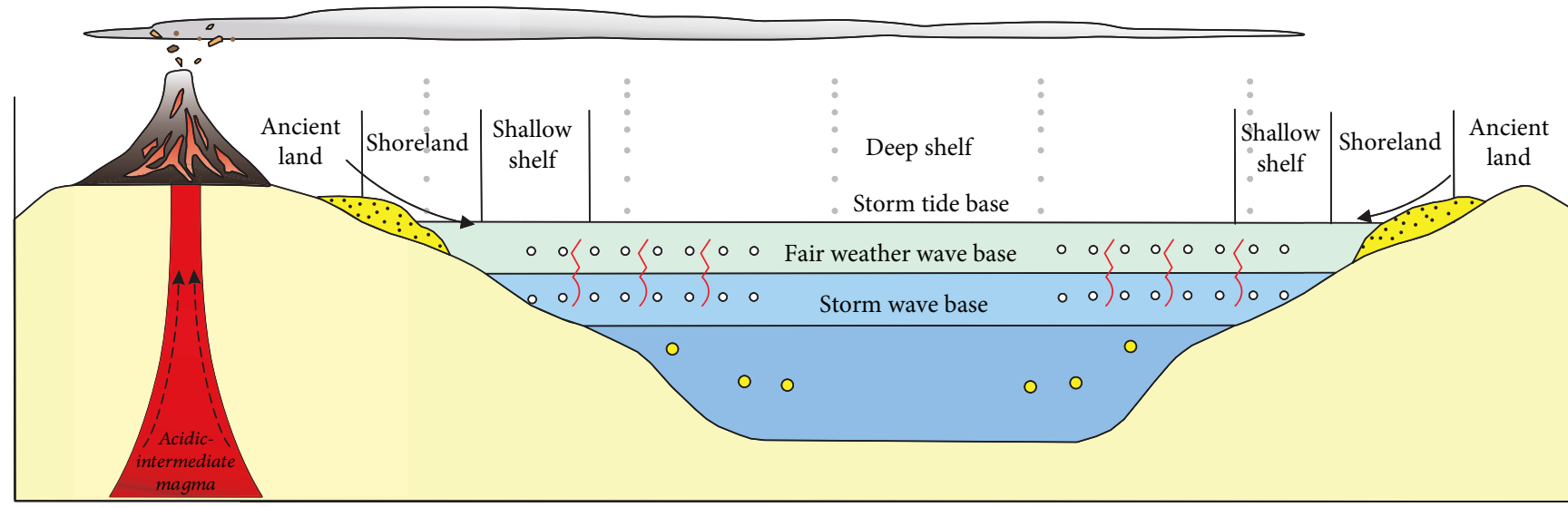

Volcanic ash
Terrigenous clastics
- Plankton

- Plankton

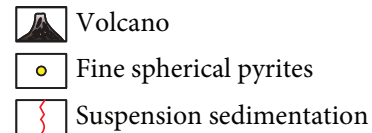

(b)

Figure 6: Models of organic matter enrichment during the deposition of the Upper Ordovician Wufeng Formation-Lower Silurian Longmaxi Formation 1st member in the Upper Yangtze area. (a) The Wufeng Formation-the lower section of the Longmaxi Formation 1st member; (b) the upper section of the Longmaxi Formation 1st member. Modified from Picard [85], Zhang et al. [30], Zhang et al. [45], Huang et al. [21], and Zou et al. [86].

(1) The siliceous minerals of the Upper Ordovician Wufeng Formation-Lower Silurian Longmaxi Formation 1st member shale in the Jiaoye-1 well, the typical well in the Upper Yangtze area, are derived from bioorigin except for the terrigenous clastic deposits, and the content of bioorigin siliceous minerals can be used as an indicator of biological productivity

(2) During the deposition period of the Wufeng Formation and the lower section of the Longmaxi Formation 1st member, on the one hand, the oxygen content of surface water is high due to the strong sealing ability of water. On the other hand, the active volcanic activity brings ash which is beneficial for biology to breed. Both factors lead to high biological productivity of the water surface. At the same time, because the sealing ability of water is strong, reducibility of the lower water is strong. Besides, active volcanic activity causes climate change, increasing the sealing of water, which makes the organic matter subsiding well preserved, leading to the high TOC content of the Wufeng Formation-the lower section of the Longmaxi Formation 1st member today

(3) During the deposition period of the upper section of the Longmaxi Formation 1st member in the Upper 
Yangtze area, on the one hand, the water becomes shallower, weakening the sealing of water, and the reduced water from the lower layer of water is brought to the surface, which caused the decrease of oxygen content in surface water. On the other hand, the volcanic activity weakens and even stops, making the source of ash with rich nutrient elements decrease. Both factors lead to low biological productivity of the water surface. At the same time, because the sealing of water weakens, the reducibility of the lower layer of water declines, and the inactive volcanic activity no longer affects the climate, which makes the little subsiding organic matter damaged, leading to the low TOC content of the upper section of the Longmaxi Formation 1st member today

\section{Data Availability}

Some of the data are contained in a published source cited in the references. All the data in this article is accessible to the readers.

\section{Additional Points}

Highlights. (1) The excess siliceous mineral content of the Upper Ordovician Wufeng Formation-Lower Silurian Longmaxi Formation 1st member in the Jiaoye-1 well, a typical well in the Upper Yangtze area, is accurately calculated and the excess siliceous mineral as a biological productivity indicator is derived from bioorigin by elemental analysis. (2) The strong sealing and active volcanic activity during the deposition of the Wufeng Formation-the lower section of the Longmaxi Formation 1st member are conducive to the improvement of biological productivity and the accumulation of sedimentary organic matter. (3) The weak sealing and gradual cessation of volcanic activity during the deposition of the upper section of the Longmaxi Formation 1st member lead to the decrease of biological productivity and the oxidative destruction of sedimentary organic matter.

\section{Conflicts of Interest}

There are no conflicts of interest with respect to the results of this paper.

\section{Authors' Contributions}

Xiaoxue Liu and Kun Zhang contributed equally to this work.

\section{Acknowledgments}

First and foremost, thanks for the support from the National Science and Technology Major Project (No. 2017ZX05035002), the Science Foundation of the Ministry of Land and Resources of China (No. 12120114046701), the Natural Science Foundation of China (No. 41472112 and No. 41728004), and the open fund from Sinopec Key Laboratory of Shale Oil/Gas Exploration and Production Technology.
Furthermore, I sincerely appreciate all coworkers who work hard with me.

\section{References}

[1] J. B. Curtis, "Fractured shale-gas systems," AAPG Bulletin, vol. 86, pp. 1921-1938, 2002.

[2] S. L. Montgomery, D. M. Jarvie, K. A. Bowker, and R. M. Pollastro, "Mississippian Barnett Shale, Fort Worth basin, north-central Texas: gas-shale play with multi-trillion cubic foot potential," AAPG Bulletin, vol. 89, no. 2, pp. 155-175, 2005.

[3] D. F. Martineau, "History of the Newark East field and the Barnett Shale as a gas reservoir," AAPG Bulletin, vol. 91, no. 4, pp. 399-403, 2007.

[4] D. M. Jarvie, R. J. Hill, T. E. Ruble, and R. M. Pollastro, "Unconventional shale-gas systems: the Mississippian Barnett Shale of north-central Texas as one model for thermogenic shale-gas assessment," AAPG Bulletin, vol. 91, no. 4, pp. 475-499, 2007.

[5] D. M. Jarvie, "Shale resource systems for oil and gas: part 2-shale-oil resource systems," AAPG Memoir, vol. 97, pp. 89-119, 2012.

[6] C. Jia, M. Zheng, and Y. Zhang, "Unconventional hydrocarbon resources in China and the prospect of exploration and development," Petroleum Exploration and Development, vol. 39, no. 2, pp. 139-146, 2012.

[7] D. Dong, Y. Wang, X. Li et al., "Breakthrough and prospect of shale gas exploration and development in China," Natural Gas Industry B, vol. 3, no. 1, pp. 12-26, 2016.

[8] X. Guo, D. Hu, Z. Wei, Y. Li, and X. Wei, "Discovery and exploration of Fuling shale gas field," China Petroleum Exploration, vol. 21, pp. 24-37, 2016.

[9] C. Zou, D. Dong, Y. Wang et al., "Shale gas in China: characteristics, challenges and prospects (II)," Petroleum Exploration and Development, vol. 43, no. 2, pp. 182-196, 2016.

[10] W. Zhao, J. Li, T. Yang, S. Wang, and J. Huang, "Geological difference and its significance of marine shale gases in South China," Petroleum Exploration and Development, vol. 43, no. 4, pp. 547-559, 2016.

[11] D. G. Hill and C. R. Nelson, "Reservoir properties of the Upper Cretaceous Lewis Shale, a new natural gas play in the San Juan Basin," AAPG Bulletin, vol. 84, article 1240, 2000.

[12] R. G. Loucks, R. M. Reed, S. C. Ruppel, and D. M. Jarvie, "Morphology, genesis and distribution of nanometer-scale pores in siliceous mudstones of the Mississippian Barnett Shale," Journal of Sedimentary Research, vol. 79, no. 12, pp. 848-861, 2009.

[13] W. Ji, Y. Song, Z. Jiang et al., "Fractal characteristics of nano-pores in the lower Silurian Longmaxi shales from the upper Yangtze Platform, South China," Marine and Petroleum Geology, vol. 78, pp. 88-98, 2016.

[14] X. Tang, Z. Jiang, S. Jiang, and Z. Li, "Heterogeneous nanoporosity of the Silurian Longmaxi Formation shale gas reservoir in the Sichuan Basin using the QEMSCAN, FIB-SEM, and nano-CT methods," Marine and Petroleum Geology, vol. 78, pp. 99-109, 2016.

[15] P. Wang, Z. Jiang, W. Ji et al., "Pore structure characterization for the longmaxi and niutitang shales in the upper Yangtze Platform, South China: evidence from focused ion beam-He ion microscopy, nano-computerized tomography and gas 
adsorption analysis," Marine and Petroleum Geology, vol. 77, pp. 1323-1337, 2016.

[16] C. Ning, Z. Jiang, Z. Gao et al., "Characteristics and controlling factors of reservoir space of mudstone and shale in Es $3 \mathrm{x}$ in the Zhanhua Sag," Marine and Petroleum Geology, vol. 88, pp. 214-224, 2017.

[17] X. Tang, Z. Jiang, S. Jiang et al., "Effects of organic matter and mineral compositions on pore structures of shales: a comparative study of lacustrine shale in Ordos Basin and marine shale in Sichuan Basin, China," Energy Exploration \& Exploitation, vol. 36, no. 1, pp. 28-42, 2018.

[18] K. Zhang, Z. Jiang, L. Yin et al., "Controlling functions of hydrothermal activity to shale gas content-taking lower Cambrian in Xiuwu Basin as an example," Marine and Petroleum Geology, vol. 85, pp. 177-193, 2017.

[19] K. Zhang, Y. Song, S. Jiang et al., "Shale gas accumulation mechanism in a syncline setting based on multiple geological factors: an example of southern Sichuan and the Xiuwu Basin in the Yangtze Region," Fuel, vol. 241, pp. 468-476, 2019.

[20] K. Zhang, Y. Song, S. Jiang et al., "Mechanism analysis of organic matter enrichment in different sedimentary backgrounds: a case study of the Lower Cambrian and the Upper Ordovician-Lower Silurian, in Yangtze region," Marine and Petroleum Geology, vol. 99, pp. 488-497, 2019.

[21] Y. Huang, Z. Jiang, K. Zhang et al., "Effect of hydrothermal activity on organic matter enrichment of shale: a case study of the Upper Ordovician and the Lower Silurian in the Lower Yangtze, South China," Minerals, vol. 8, no. 11, p. 495, 2018.

[22] K. Zhang, Y. Song, C. Jia et al., "Vertical sealing mechanism of shale and its roof and floor and effect on shale gas accumulation, a case study of marine shale in Sichuan basin, the Upper Yangtze area," Journal of Petroleum Science and Engineering, vol. 175, pp. 743-754, 2019.

[23] X. Wei, Z. Zhao, Q. Wang, Z. Liu, M. Zhou, and H. Zhang, "Comprehensive evaluation of geological conditions of the shale gas in Upper Ordovician Wufeng Formation-Lower Silurian Longmaxi Formation in Dingshan area, Qijiang, southeastern Sichuan," Geological Review, vol. 63, pp. 153164, 2017.

[24] K. Zhang, Z. Jiang, X. Xie et al., "Lateral percolation and its effect on shale gas accumulation on the basis of complex tectonic background," Geofluids, vol. 2018, Article ID 5195469, 11 pages, 2018.

[25] T. Guo, "Evaluation of highly thermally mature shale-gas reservoirs in complex structural parts of the Sichuan Basin," Journal of Earth Science, vol. 24, no. 6, pp. 863-873, 2013.

[26] C. Li and C. Ou, "Modes of Shale-gas enrichment controlled by tectonic evolution," Acta Geologica Sinica - English Edition, vol. 92, no. 5, pp. 1934-1947, 2018.

[27] C. Ou, C. Li, Z. Rui, Z. Rui, and Q. Ma, "Lithofacies distribution and gas-controlling characteristics of the WufengLongmaxi black shales in the southeastern region of the Sichuan Basin, China," Journal of Petroleum Science and Engineering, vol. 165, pp. 269-283, 2018.

[28] H. Nie, S. Bao, B. Gao et al., "A study of shale gas preservation conditions for the Lower Paleozoic in Sichuan Basin and its periphery," Earth Science Frontiers, vol. 19, pp. 280-294, 2012.

[29] W. Xia, B. Yu, and M. Sun, "Depositional settings and enrichment mechanism of organic matter of the black shales at the bottom of niutitang formation, lower cambrian in southeast chongqing: a case study from well yuke 1," Acta Geologica Sinica - English Edition, vol. 89, no. s1, p. 287, 2015.

[30] Y. Zhang, Z. He, S. Jiang et al., "Marine redox stratification during the early Cambrian (ca. 529-509 Ma) and its control on the development of organic-rich shales in Yangtze Platform," Geochemistry, Geophysics, Geosystems, vol. 18, no. 6, pp. 2354-2369, 2017, In Chinese.

[31] Z. Qiu, Z. Jiang, D. Dong et al., “Organic matter enrichment model of the shale in Wufeng-Longmaxi formation of Wuxi area," Journal of China University of Mining \&Technology, vol. 46, pp. 1134-1143, 2017.

[32] H. K. Holdaway and C. J. Clayton, "Preservation of shell microstructure in silicified brachiopods from the upper cretaceous Wilmington sands of Devon," Geological Magazine, vol. 119, no. 4, pp. 371-382, 1982.

[33] K. H. Wedepohl, "Environmental influences on the chemical composition of shales and clays," Physics and Chemistry of the Earth, vol. 8, pp. 307-333, 1971.

[34] M. Adachi, K. Yamamoto, and R. Sugisaki, "Hydrothermal chert and associated siliceous rocks from the northern Pacific their geological significance as indication od ocean ridge activity," Sedimentary Geology, vol. 47, no. 1-2, pp. 125-148, 1986.

[35] K. Yamamoto, "Geochemical characteristics and depositional environments of cherts and associated rocks in the Franciscan and Shimanto Terranes," Sedimentary Geology, vol. 52, no. 1-2, pp. 65-108, 1987.

[36] D. Li, J. Li, J. Huang, S. Wang, and S. Wang, "An important role of volcanic ash in the formation of shale plays and its inspiration," Natural Gas Industry, vol. 34, pp. 56-65, 2014.

[37] Y. Shu, Y. Lu, Z. Liu, C. Wang, and H. Mao, "Development characteristics of bentonite in marine shale and its effect on shale reservoir quality: a case study of Wufeng Formation to Member 1 of Longmaxi Formation, Fuling area," Acta Petrolei Sinica, vol. 38, pp. 1371-1380, 2017.

[38] L. Wu, Y. Lu, S. Jiang, X. Liu, and G. He, "Effects of volcanic activities in Ordovician Wufeng-Silurian Longmaxi period on organic-rich shale in the Upper Yangtze area, South China," Petroleum Exploration and Development, vol. 45, no. 5, pp. 862-872, 2018.

[39] S. Wang, D. Dong, Y. Wang, X. Li, and J. Huang, "Geochemical characteristics the sedimentation environment of the gas-enriched shale in the Silurian Longmaxi Formation in the Sichuan Basin," Acta Metallurgica Sinica, vol. 34, pp. 1203-1212, 2015.

[40] C. Zou, D. Dong, Y. Wang et al., "Shale gas in China: characteristics, challenges and prospects (I)," Petroleum Exploration and Development, vol. 42, no. 6, pp. 753-767, 2015.

[41] C. Mou, X. Wang, Q. Wang et al., "Relationship between sedimentary facies and shale gas geological conditions of the Lower Silurian Longmaxi Formation in southern Sichuan Basin and its adjacent areas," Journal of Palaeogeography, vol. 18, pp. 457-471, 2016.

[42] M. Zhu, J. Zhang, A. Yang, G. Li, M. Steiner, and B. D. Erdtmann, "Sinian-Cambrian stratigraphic framework for shallow- to deep-water environments of the Yangtze Platform: an integrated approach," Progress in Natural Science, vol. 13, no. 12, pp. 951-960, 2003.

[43] M. Zhu, L. Babcock, and S. Peng, "Advances in Cambrian stratigraphy and paleontology: integrating correlation techniques, paleobiology, taphonomy and paleoenvironmental reconstruction," Palaeoworld, vol. 15, no. 3-4, pp. 217-222, 2006. 
[44] Z. Liu, B. Gao, Y. Zhang, W. Du, D. Feng, and H. Nie, “Types and distribution of the shale sedimentary facies of the lower cambrian in Upper Yangtze area, South China," Petroleum Exploration and Development, vol. 44, no. 1, pp. 20-31, 2017.

[45] K. Zhang, Z. Li, S. Jiang et al., "Comparative analysis of the siliceous source and organic matter enrichment mechanism of the Upper Ordovician-Lower Silurian Shale in the UpperLower Yangtze Area," Minerals, vol. 8, no. 7, p. 283, 2018.

[46] Z. Li, L. Zhang, and C. M. Powell, "South China in Rodinia: part of the missing link between Australia-East Antarctica and Laurentia?,” Geology, vol. 23, no. 5, pp. 407-410, 1995.

[47] Z. Li, X. Li, H. Zhou, and P. D. Kinny, "Grenvillian continental collision in South China: new SHRIMP U-Pb zircon results and implications for the configuration of Rodinia," Geology, vol. 30, no. 2, pp. 163-166, 2002.

[48] J. Wang and Z. Li, "History of Neoproterozoic rift basins in South China: implications for Rodinia break-up," Precambrian Research, vol. 122, no. 1-4, pp. 141-158, 2003.

[49] L. Mei, D. Deng, C. Shen, and Z. Liu, "Tectonic dynamics and marine hydrocarbon accumulation of Jiangnan-Xuefeng uplift," Geological Science and Technology Information, vol. 31, pp. 85-93, 2012.

[50] Z. Wang, H. Zhou, X. Wang, X. Jing, and Y. Ma, "First report on zircon U-Pb geochronology of K-bentonites from the lower part of the Upper Ordovician Taoqupo Formation in Yaoxian, Shanxi," Acta Geologica Sinica, vol. 92, pp. 330-340, 2018.

[51] H. Luo, L. Pan, and R. He, "Geochemical characteristics and geological significance of Longmaxi Formation of Late Ordovician-Early Silurian in Mayangzhai Area, Hubei Province," Res. Environ. Eng., vol. 31, pp. 1-5-12, 2017.

[52] Y. Hu, W. Sun, X. Ding, F. Wang, M. Ling, and J. Liu, "Volcanic event at the Ordovician-Silurian boundary: the message from K-bentonite of Yangtze Block," Acta Petrolei Sinica, vol. 25, pp. 3298-3308, 2009.

[53] Z. Tang, F. Liu, X. Dong et al., "SHRIMP U-Pb zircon dating for the Early-Middle Ordovician K-bentonites in JiangshanChangshan-Yushan, Zhejiang-Jiangxi border area," Earth Science, pp. 1-15, 2018, http://kns.cnki.net/kcms/detail/42 .1874.P.20180620.1829.096.html.

[54] X. Guo, D. Hu, Y. Li, Z. Wei, X. Wei, and Z. Liu, "Geological factors controlling shale gas enrichment and high production in Fuling shale gas field," Petroleum Exploration and Development, vol. 44, no. 4, pp. 513-523, 2017.

[55] B. Jones and D. A. C. Manning, "Comparison of geochemical indices used for the interpretation of palaeoredox conditions in ancient mudstones," Chemical Geology, vol. 111, no. 1-4, pp. 111-129, 1994.

[56] L. Chen, Y. Lu, S. Jiang, J. Li, T. Guo, and C. Luo, "Heterogeneity of the Lower Silurian Longmaxi marine shale in the southeast Sichuan Basin of China," Marine and Petroleum Geology, vol. 65, pp. 232-246, 2015.

[57] J. Zhao, Z. Jin, Z. Jin, Y. Geng, X. Wen, and C. Yan, “Applying sedimentary geochemical proxies for paleoenvironment interpretation of organic-rich shale deposition in the Sichuan Basin, China," International Journal of Coal Geology, vol. 163, pp. 52-71, 2016.

[58] S. Wang, D. Dong, Y. Wang, X. Li, J. Huang, and Q. Guan, "Sedimentary geochemical proxies for paleoenvironment interpretation of organic-rich shale: a case study of the Lower Silurian Longmaxi Formation, Southern Sichuan Basin,
China," Journal of Natural Gas Science and Engineering, vol. 28, pp. 691-699, 2016.

[59] K. Bostrom, T. Kraemer, and S. Gratner, "Provenance and accumulation rates of opaline silica, $\mathrm{Al}, \mathrm{Ti}, \mathrm{Fe}, \mathrm{Mn}, \mathrm{Cu}, \mathrm{Ni}$ and Co in Pacific pelagic sediments," Chemical Geology, vol. 11, no. 2, pp. 123-148, 1973.

[60] R. W. Murray, T. B. M. R. Buchholtz, and D. C. Gerlach, "Rare earth, major, and trace elements in chert from the Franciscan Complex and Monterey Group, California: Assessing REE sources to fine-grained marine sediments," Geochimica et Cosmochimica Acta, vol. 55, no. 7, pp. 1875-1895, 1991.

[61] J. Liu and M. Zheng, "Geochemistry of hydrothermal sedimentary silicalite," Acta Geologica Sichuan, vol. 13, pp. 110-118, 1993.

[62] J. M. Yang, D. H. Wang, J. Mao, Z. H. Zhang, Z. C. Zhang, and W. Zhilin, "The petrochemical research method for silicalite and its application to the "Jingtieshan Type" iron deposits," Acta Petrologica Et Mineralogica, vol. 18, no. 2, pp. 108-120, 1999.

[63] J. Liu, Y. Li, Y. Zhang, S. Liu, and Y. Cai, "Evidences of biogenic silica of Wufeng-Longmaxi Formation shale in Jiaoshiba area and its geological significance," Journal of China University of Petroleum (Edition of Natural Science), vol. 41, pp. 34-41, 2017.

[64] D. J. K. Ross and R. M. Bustin, "Investigating the use of sedimentary geochemical proxies for paleoenvironment interpretation of thermally mature organic-rich strata: examples from the Devonian-Mississippian shales, Western Canadian Sedimentary Basin," Chemical Geology, vol. 260, no. 1-2, pp. 1-19, 2009.

[65] L. Hou, M. Liu, H. Yan, S. Xu, D. Ou, and X. Lin, "Distribution of biogenic silica in tidal flat sediments of Yangtze Estuary and its influence factors," China Environmental Science, vol. 27, pp. 665-669, 2007.

[66] O. Romero and D. Hebbeln, "Biogenic silica and diatom thanatocoenosis in surface sediments below the Peru-Chile Current: controlling mechanisms and relationship with productivity of surface waters," Marine Micropaleontology, vol. 48, no. 1-2, pp. 71-90, 2003.

[67] X. Ye, S. Liu, Y. Zhao, and J. Zhang, "The distribution of biogenic silica in the sediments of the East China Sea and the Yellow Sea and its environmental signification," China Environmental Science, vol. 24, pp. 265-269, 2004.

[68] T. J. Algeo and T. W. Lyons, "Mo-total organic carbon covariation in modern anoxic marine environments: implications for analysis of paleoredox and paleohydrographic conditions," Paleoceanography, vol. 21, no. 1, article PA1016, 2006.

[69] X. Xiong, J. Wang, Q. Yu et al., "Element geochemistry inversion of the environment and background of organic-rich black shale formations: a case study of the Wufeng-Longmaxi black shale in the Tianba section in northeastern Chongqing," Natural Gas Industry, vol. 35, pp. 25-32, 2015.

[70] Y. Wu, T. Fan, S. Jiang, and X. Yang, "Lithofacies and sedimentary sequence of the lower Cambrian Niutitang shale in the upper Yangtze platform, South China," Journal of Natural Gas Science and Engineering, vol. 43, pp. 124-136, 2017.

[71] J. Chen, S. Zhang, S. Sun, and Q. Wu, "Main factors influencing marine carbonate source rock formation," Acta Geologica Sinica, vol. 80, pp. 467-472, 2006.

[72] L. Cheng, Y. Wang, H. Chen, Y. Wang, and Y. Zhong, "Sedimentary and burial environment of black shales of Sinian to 
Early Palaeozoic in Upper Yangtze region," Acta Petrologica Sinica, vol. 29, pp. 2906-2912, 2013.

[73] D. R. Kolata, J. K. Frost, and W. D. Huff, “Chemical correlation of K-bentonite beds in the Middle Ordovician Decorah Subgroup, upper Mississippi Valley," Geology, vol. 15, no. 3, pp. 208-211, 1987.

[74] W. D. Huff, S. M. Bergstrom, and D. R. Kolata, "Gigantic Ordovician volcanic ash fall in North America and Europe: biological, tectonomagmatic, and event-stratigraphic significance," Geology, vol. 20, no. 10, pp. 875-878, 1992.

[75] J. A. Winchester and P. A. Floyd, "Geochemical discrimination of different magma series and their differentiation products using immobile elements," Chemical Geology, vol. 20, pp. 325-343, 1977.

[76] A. Genin, B. Lazar, and S. Brenner, "Vertical mixing and coral death in the Red Sea following the eruption of Mount Pinatubo," Nature, vol. 377, no. 6549, pp. 507-510, 1995.

[77] Y. Ma, M. Fan, Y. Lu et al., "Geochemistry and sedimentology of the Lower Silurian Longmaxi mudstone in southwestern China: implications for depositional controls on organic matter accumulation," Marine and Petroleum Geology, vol. 75, pp. 291-309, 2016.

[78] Y. Li, T. Zhang, G. S. Ellis, and D. Shao, "Depositional environment and organic matter accumulation of Upper OrdovicianLower Silurian marine shale in the Upper Yangtze Platform, South China," Palaeogeography, Palaeoclimatology, Palaeoecology, vol. 466, pp. 252-264, 2017.

[79] Q. Gong, X. Wang, L. Zhao et al., "Mercury spikes suggest volcanic driver of the Ordovician-Silurian mass extinction," Scientific Reportsvolume, vol. 7, no. 1, article 5304, 2017.

[80] D. S. Jones, A. M. Martini, D. A. Fike, and K. Kaiho, “A volcanic trigger for the Late Ordovician mass extinction? Mercury data from south China and Laurentia," Geology, vol. 45, no. 7, pp. 631-634, 2017.

[81] Y. Lu, Y. Ma, and Y. Wang, "The sedimentary response to the major geological events and lithofacies characteristics of Wufeng Formation-Longmaxi Formation in the Upper Yangtze Area," Earth Science, vol. 42, pp. 1169-1184, 2017.

[82] N. Olgun, S. Duggen, D. Andronico et al., "Possible impacts of volcanic ash emissions of Mount Etna on the primary productivity in the oligotrophic Mediterranean Sea: results from nutrient-release experiments in seawater," Marine Chemistry, vol. 152, pp. 32-42, 2013.

[83] B. Langmann, K. Zakšek, M. Hort, and S. Duggen, "Volcanic ash as fertiliser for the surface ocean," Atmospheric Chemistry and Physics, vol. 10, no. 8, pp. 3891-3899, 2010.

[84] S. Duggen, P. L. Croot, U. Schacht, and L. Hoffmann, "Subduction zone volcanic ash can fertilize the surface ocean and stimulate phytoplankton growth: evidence from biogeochemical experiments and satellite data," Geophysical Research Letters, vol. 34, no. 1, pp. 95-119, 2007.

[85] M. D. Picard, "Classification of fine-grained sedimentary rocks," Journal of Sedimentary Research, vol. 41, pp. 179-195, 1971.

[86] C. Zou, Z. Yang, J. Cui et al., "Formation mechanism, geological characteristics and development strategy of nonmarine shale oil in China," Petroleum Exploration and Development, vol. 40, no. 1, pp. 15-27, 2013. 

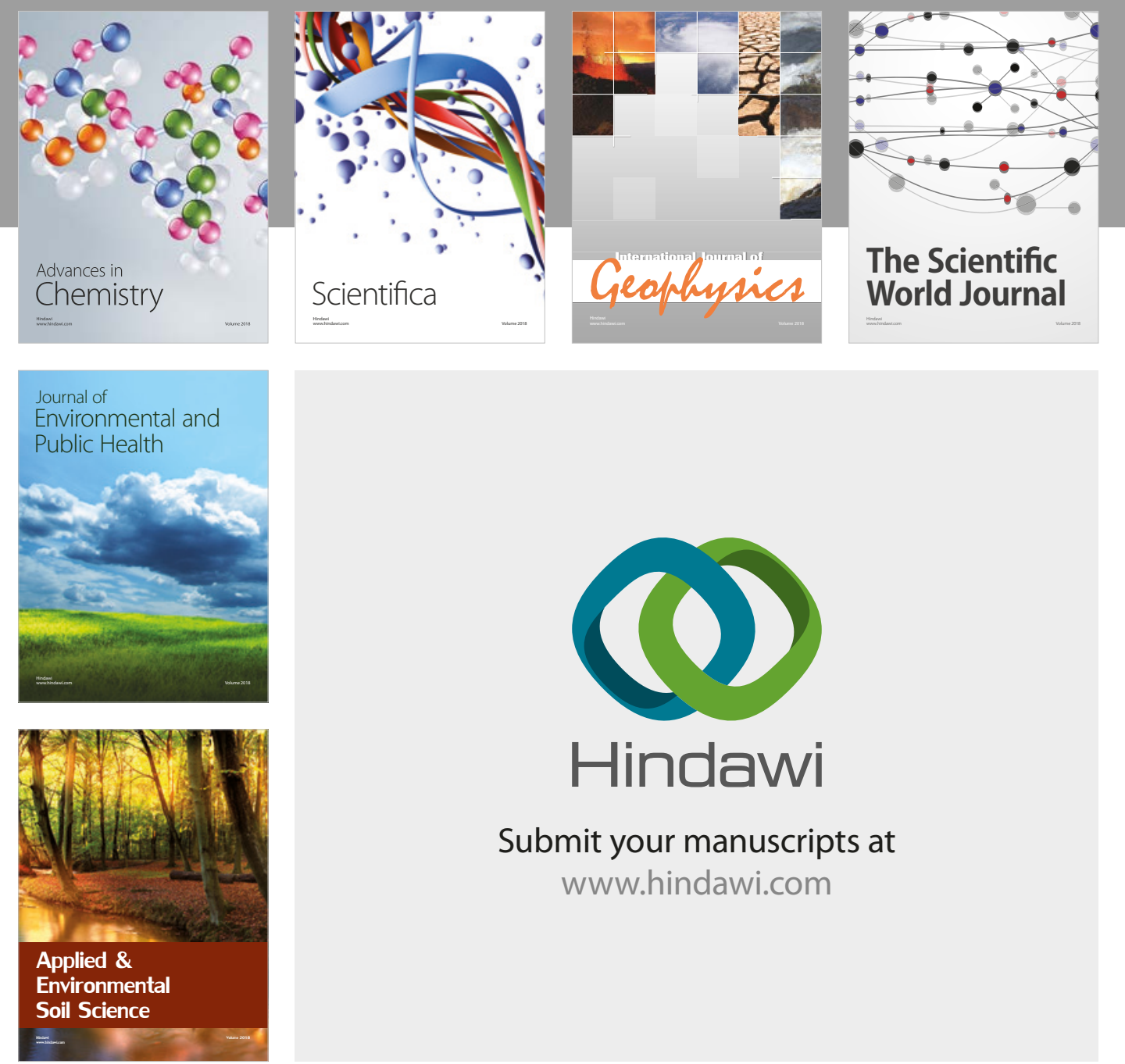

The Scientific

\section{World Journal}
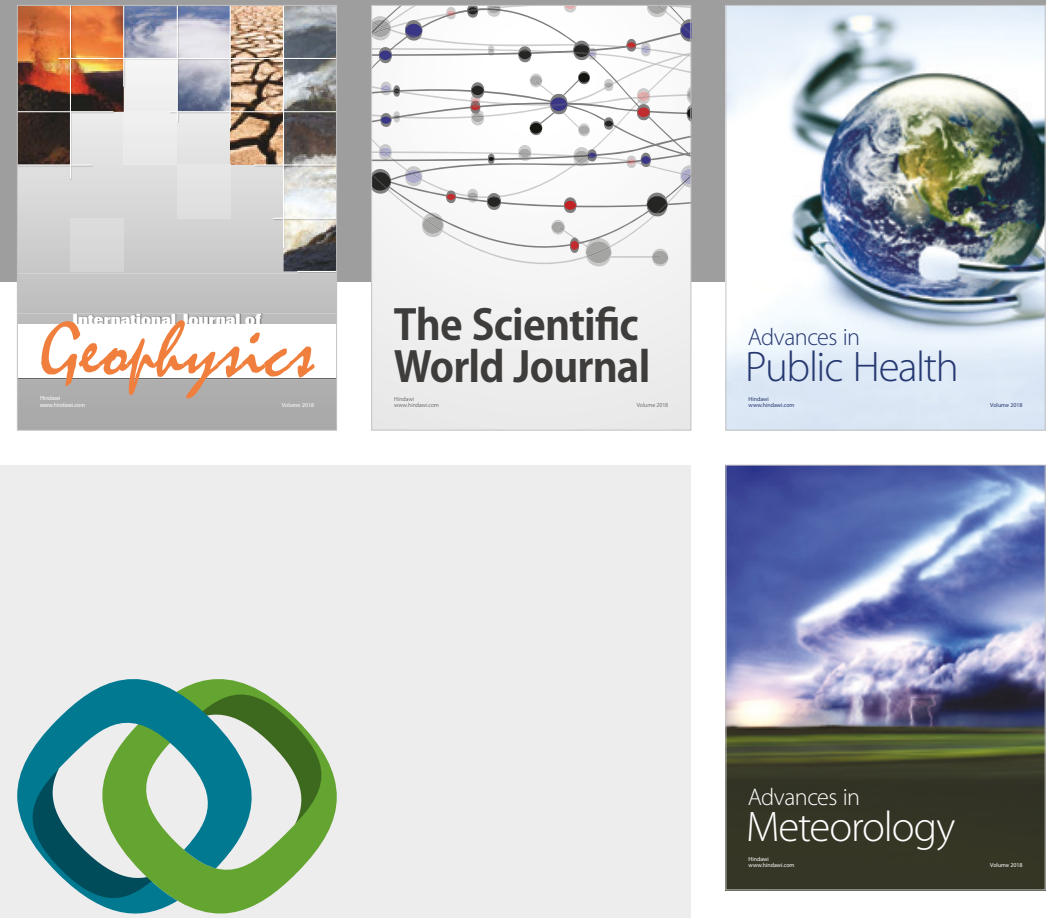

Advan

Public Health

\section{Hindawi}

Submit your manuscripts at

www.hindawi.com
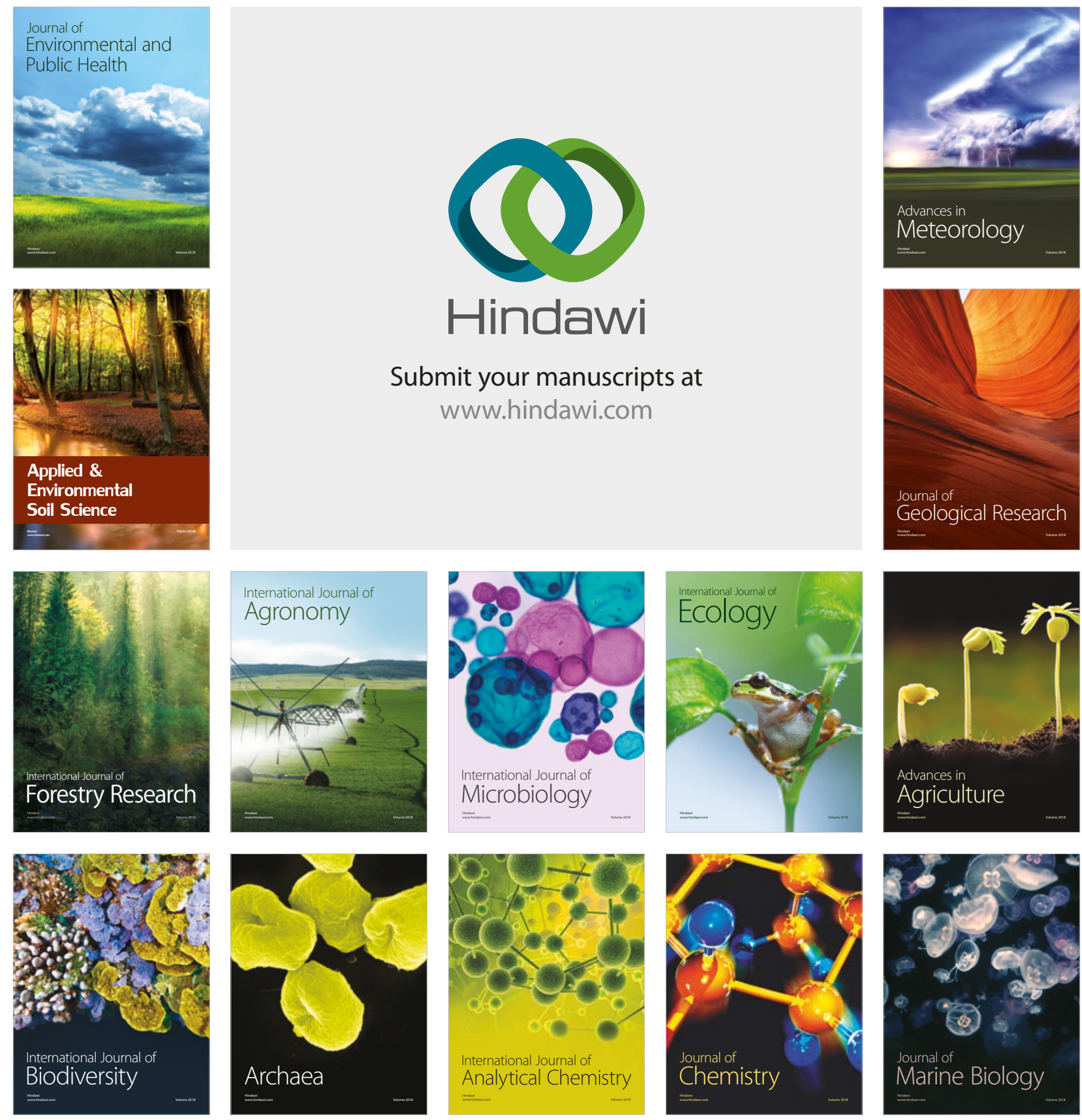